\title{
Prehistoria de África
}

\author{
MARIo MENÉndez FERnÁNDEZ*
}

Editorial Síntesis, en la colección de Prehistoria, ha presentado hasta la fecha una selección de libros de carácter general muy acertada en sus contenidos, aunque excesivamente dirigida a cumplir la misión de manual universitario, ya que se ajusta al temario estándar propuesto en la mayoría de las universidades españolas. La aparición del libro objeto de este comentario rompe esta línea editorial, pues desgraciadamente la prehistoria africana no recibe la atención debida en la mayoría de las asignaturas troncales de los programas vigentes en nuestras universidades, y excepcionalmente aparece en asignaturas optativas formando parte de contenidos muy específicos como el origen del género humano, u otros más generales como la transformación neolítica, aunque en este caso como hermana pobre de los cambios contemporáneos en el Próximo Oriente. En este sentido, probablemente este título no sea tan comercial como los anteriores, pero constituye ese tipo de obras que van configurando un fondo editorial específico y exclusivo que dan prestigio a un determinado sello ${ }^{1}$.

La arqueología española ha pecado tradicionalmente de aislacionismo, con honrosas y escasas excepciones, siendo raras no sólo las misiones arqueológicas españolas fuera de nuestro país, sino el mero interés por la arqueología foránea, en general, y por la africana en particular. Este provincianismo científico, hoy susceptible de ser definido como autonómico en algunos casos, contradice en su raíz la propia naturaleza afronteriza de la Prehistoria, y suele aunar la limitación geográfica preestablecida por los autores con la limitación conceptual de los mismos. Por suerte este pano-

Prof. Titular del Departamento de Prehistoria. UNED.

Arqueología Prehistórica de África. FeRnÁndez MARTínez, V.M., 1996. Edit. Síntesis. Historia Universal. Prehistoria, n. ${ }^{\circ}$ 9. Madrid. 263 p. 
rama está cambiando en los últimos años, y ya no son tan excepcionales los componentes o equipos completos de nuestro país que trabajan en otros continentes interesados por la investigación de culturas ajenas, como muestra el hecho de que en la actualidad se estén desarrollando en África cinco proyectos españoles, con diferente procedencia y fuente de financiación, ocupando desde el Mahgreb hasta la selva tropical, en lo geográfico, y desde los remotos orígenes del género Homo en África centrooriental hasta el Imperio Nuevo egipcio. En este sentido, el libro de V. Fernández viene a sancionar esta nueva situación y constituye un hito en la bibliografía arqueológica de autores en castellano.

África es un continente enorme y variado, cuna de la humanidad. Si los orígenes africanos de nuestro género primero y de nuestra especie después, le confieren un comienzo muy anterior a la prehistoria europea y asiática, no digamos ya a la americana, su tardía entrada en la historia escrita, sobre todo en el ámbito subsahariano, dilata igualmente su prehistoria reciente. Esta amplitud cronológica, sumada a la diversidad cultural que corre pareja a la variedad geográfica y lingüística, añade un plus de dificultad a la arqueología prehistórica africana, lo que hace difícil la elaboración de obras generales. Son escasas las buenas síntesis recientes con carácter general, como el libro de Phillipson (African Archaeology, 1993, 2. ${ }^{a}$ ed., Cambridge U.P.) y no existía hasta el momento ninguna en castellano de estas características, pues la obra pionera y única de Pericot y Tarradell: Manual de Prehistoria africana, CSIC 1963, hace tiempo que está agotada y, naturalmente, muy superada por los más de treinta años de descubrimientos e investigación transcurridos desde su publicación. Por ello debemos agradecer nuevamente al autor y a la editorial la publicación de este título.

La obra recoge los capítulos que cabría esperar en una publicación de este tipo y añade otros específicamente originales. Veamos unos y otros. Entre los primeros encontramos los relativos al contexto geográfico y cultural, origen del género humano, diferentes fases paleolíticas (Early Stone Age; Middle Stone Age y Late Stone Age), arte rupestre, origen de la producción de alimentos, edad del hierro y primeros estados. Entre los segundos aparece una breve síntesis de la prehistoria de las Islas Canarias y una detallada descripción de la historia de la investigación española en el continente africano.

Quienes han trabajado sobre el Pleistoceno africano saben muy bien la dificultad de acceder a una comprensión mínimamente aceptable sobre la climatología de la primera parte del cuaternario del continente. Incluso en la relativa al Holoceno temprano. La información, frecuentemente contra- 
dictoria, está dispersa en bibliografía a veces de difícil acceso y generalmente referida a áreas restringidas. El autor refleja este problema, pero se hubiera agradecido un tratamiento más amplio y homogeneo del contexto geográfico - tanto del biotopo como de la biocenosis- que, por otra parte, aparece tratado en cada uno de los capítulos.

La moderna arqueología africana integra a los actuales pueblos con sus antepasados prehistóricos utilizando la lingüística y la genética de poblaciones. Los recientes estudios de léxico-estadística y glotocronología permiten rastrear el origen de algunos términos indicadores de actividades específicas (por ejemplo las ganaderas o agrícolas) así como señalar las posibles migraciones y su cronología. Los estudios sobre el ADN humano o de especies animales aclaran, igualmente, los aspectos anteriores $u$ otros aún más relevantes, como la aparición del hombre moderno en un momento temprano y en un contexto MSA del paleolítico africano; pero también el origen autóctono -y también temprano- de la domesticación de algunas especies animales que algunos autores suponían importadas desde Asia. La actualidad en el tratamiento de estos temas y la claridad con que se exponen es digna de un elogio especial, por lo inusual en la bibliografía al uso en castellano.

El capítulo dedicado al origen del género humano resume con gran concisión y claridad el estado de la cuestión. Sin caer en el recurso fácil de las descripciones, incorpora los nuevos especímenes, como el australopithecus ramidus, y las más recientes denominaciones taxonómicas, como Homo ergaster, incluyendo la "lectura social" de los restos y las interpretaciones ya tradicionales de los mismos, como son las tesis de Isaac, Lovejoy, Binford, etc. Todo ello en unas pocas páginas (para un tratamiento más extenso esta misma colección ha publicado la obra de M. ${ }^{a} \mathrm{~A}$. Querol, 1991: De los primeros seres humanos, y más recientemente el trabajo monográfico de M. Domínguez-Rodrigo, 1996: En el principio de la humanidad) referidas un tema tan clave como repetido en la bibliografía arqueológica usual y las publicaciones de divulgación científica.

Los diferentes tipos humanos entroncan con las diferentes fases paleolíticas, ya tratadas de forma más "artefactual» y divididas por zonas. No cabe duda de lo adecuado de esta presentación desde el punto de vista de la metodología tradicional universitaria, o de las exigencias que plantea tener que mostrar una mínima erudición en lo relativo a las industrias, pero seguramente tampoco se dudará de lo poco atractivo que resulta para el lector, incluido el especialista. V. Fernández aligera esto con referencias de gran interés a las recientes cronologías e interpretaciones (yacimientos como los surafricanos de Border Cave o Klasies River, donde se han lo- 
calizado restos de hombre moderno arcaico asociado a industrias de la MSA - Pietersburg y Bambata-, en una cronología que se retrotrae hasta 120.000 BP., con intrusiones de industrias laminares Howieson's Port) y datos genéticos - mtADN-, frecuentemente ausentes en la bibliografía en castellano $y$, sin duda, determinantes para una correcta comprensión de la polémica científica sobre la aparición del hombre moderno en Europa y los orígenes de nuestro Paleolítico Superior.

El arte rupestre aparece separado en dos capítulos. Por un lado los santuarios de África Oriental y Meridional, y por otro los saharianos. Los primeros se dividen en dos estilos: naturalista y esquemático; los segundos se describen según los grupos tradicionales: bubaliense, equidiense, etc. Sólo se aceptan como paleolíticos - LSA - los naturalistas del primer grupo, con apoyo indudable en el arte mueble de Apolo 11 y Wonderwerk. Sin entrar en los aspectos cronológicos, tan subjetivamente polémicos como pueden serlo las cronologías estilisticas del arte rupestre de Europa occidental, la división del arte en dos capítulos puede dar la sensación de dos entidades radicalmente diferentes, lo que no se corresponde con la realidad arqueológica ni con la intención del autor. Así, la excelente síntesis que se hace del pensamiento de $D$. Lewis-Williams sobre la interpretación chamánica del significado del arte no se restringe a los bosquimanos de África del Sur, sino que incluso es ya una clave interpretativa más del arte prehistórico europeo, cuanto más del africano en general.

El capítulo dedicado al origen de la producción de alimentos muestra la erudición y el sesgo sahariano que eran de esperar en quien trabaja en la actualidad sobre ese momento y en esa zona. La dificultad de no contar con buenos yacimientos en posición primaria (por lo general se trata de niveles revueltos, o de muy débil potencia, sin estructuras) le resta la brillantez que esta fase tiene en otras zonas, como Próximo Oriente. Sin embargo, la consideración de informaciones zooarqueológicas -incluyendo datos de ADN animal-; los escasos y frecuentemente controvertidos restos botánicos, con el problema de la identificación de los cereales africanos cultivados - sorgo y mijo-; los datos lingüísticos, que a través de la glotocronología permiten datar la aparición de vocablos relacionados con las actividades productivas; y las cerámicas e industrias líticas, que con los datos anteriores ayudan a desarrollar una visión global y crítica de la aparición de la economía productiva en el continente africano de forma autóctona y de su expansión por el mismo.

Desgraciadamente el neolítico africano no suele formar parte de los programas universitarios europeos. Tal vez sea porque no ha tenido la "lectura social" de sus restos que sí se ha aplicado a la misma fase en 
otras áreas. En los últimos años los estudios sobre este período han experimentado un notable avance, sobre todo lo referido a la cuenca nilótica. Por ello, es de agradecer que se nos ofrezcan en esta obra con referencias tan profusas y actuales, ya que en el peor de los casos, sino despiertan interés en sí mismos, al menos servirán como referencia, por lo específico de su modelo, de fenómenos equivalentes desarrollados en ámbitos más familiares.

Los capítulos siguientes -Edad del Hierro y Civilizaciones africanasenlazan la prehistoria con los imperios antiguos, Egipto y Roma en el norte y noreste, y con el mundo moderno europeo o asiático para el resto del continente. Suele ser un período muy desconocido, o frecuentemente fabulado, hasta las descripciones de viajeros y explotadores contemporáneos.

Finalmente, debemos hacer mención a aquellos capítulos que hemos definido como originales. El primero está felizmente dedicado a la prehistoria de las Islas Canarias. Este archipiélago, por su peculiar situación, no suele aparecer ni en las sintesis dedicadas a África ni en aquellas referidas a la Península lbérica, por lo que frecuentemente constituye un vacio no sólo en el conocimiento de la prehistoria española, sino también en los programas oficiales. A este vacío ha contribuido la inexistencia, que nosotros conozcamos, de síntesis generales de la arqueología prehistórica de las islas. El capítulo que le dedica V. Fernández es obligadamente breve, pero muy claro en la compleja periodización para las diferentes islas. Además, ofrece hasta 14 títulos en la bibliografía, casi todos de finales de los años 80 y de principios de los 90 , que permiten al lector interesado ampliar el resumen realizado en diez y ocho páginas, remitiéndolo a trabajos más especializados.

Finalmente se cierra el libro con un resumen de las actividades arqueológicas españolas en el continente africano. Se estructura el capítulo en dos grandes bloques: las campañas llevadas a cabo al amparo de las actividades coloniales españolas en África, y aquellas que tuvieron como marco la campaña de salvamento promovida por la UNESCO durante los años 60 con motivo de la construcción de la presa de Aswan, en la Baja Nubia. Esta última, bajo la dirección del profesor Almagro Basch, puso a especialistas españoles en contacto con misiones de todo el mundo, sentando las bases de nuestra participación activa en el concierto arqueológico internacional. De ella se derivaron posteriores trabajos en el continente africano, de los cuales el autor del libro fue un directo participante; y sin duda la causa remota de que hoy estemos comentando este trabajo.

Como resumen final queremos destacar una característica que está presente en toda la obra. No se trata solamente de recoger e interpretar fiel- 
mente el registro arqueológico africano; ni siquiera de exponerlo con rigor y claridad. Más allá de este logrado propósito se aprecia en toda la obra una singular atracción hacia lo descrito; un intento de desterrar el eurocentrismo que tan presente ha estado en toda la literatura, no sólo la arqueológica, sobre África. Esta postura de partida relega términos cargados de sentimiento colonialista o, incluso, claramente racista. Por ello, no sólo debe agradecerse a $\mathrm{V}$. Fernández que haya hecho un buen manual sobre un campo poco frecuentado en nuestro país como es la arqueología prehistórica de África, sino que lo haya hecho con el apasionamiento del que ama su trabajo y lo relacionado con él y, además, disfruta realizándolo. 